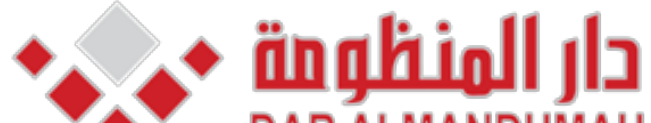 DAR ALMANDUMAH

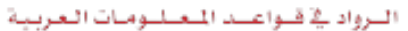

THE ARAB AND EGYPTIAN INFLUENCE IN SWAHILI LANGUAGE AND

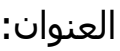

LITERATURE

مجلة كلية اللغات والترجمة

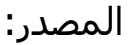

جامعة الازهر - كلية اللغات والترجمة

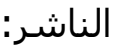

Al A'sar, Ayman Ibrahim

$$
\text { المجلم المولف الرئيسي: }
$$

$3 \varepsilon$

نعم

2012

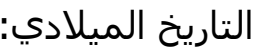

يوليو

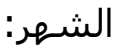

$100-127$

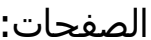

752542

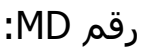

بحوث ومقالات

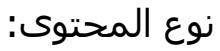

AraBase

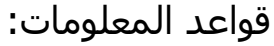

اللغة السواحلية، النقد اللغوي، مصر

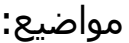

http://search.mandumah.com/Record/752542

رابط: 


\title{
THE ARAB AND EGYPTIAN INFLUENCE IN SWAHILI LANGUAGE
} AND LITERATURE

\author{
By \\ DR. Ayman Ibrahim A1 A'sar \\ Associate Professor \\ Swahili Literature \\ Faculty of Languages and Translation \\ Al-Azhar University \\ 2012
}




\section{Introduction}

Afro-Arab relations are rooted in ancient historical ties built on shared historical, geographical, social, economic, cultural, religious and political foundations which affirm the depth of these shared relations from time immemorial. There is plenty of evidence that points to the fact that Arabs found their way to the East Coast of Africa long before the advent of Islam, and got a foothold on the region as time went by, given that the only thing that separated the two regions was the Red Sea. Subsequently, the region witnessed the growth of Arab-Islamic culture whereby towns sprung up with Arab-Islamic features manifesting themselves in many facets of life including: clothing, food, customs and traditions which were essentially Islamic and Arab in nature. This had an impact on Swahili language and its various literary forms.

These developments were helped by the south-western winds blowing in the direction of north-east between the months of June and October when Arab traders moved from their homeland and settled along the East Coast of Africa. This situation persisted for more than 1000 years and given that the tides required them to wait along the Coast for a period of more than three months until the tide changed direction, there was interaction between them and the locals which resulted in intermarriage between the two peoples. This gave rise to a new generation of people who carried Afro-Arab features and who spoke Swahili language, a Bantu language with Arabic vocabulary. On the other hand, Arabic influence was not limited to the Eastern region, but also spread from the north in Egypt and Sudan due to the spread of Islam in the region, and particularly in Egypt which was regarded the take off point towards the west and south. This influence by Egypt started before the coming of Islam to Egypt through expeditions by 
ancient Egyptians who went out in search of the source of the River Nile. This influence grew after the spread of Islam and Arabic language amongst Egyptians through both trade and religious caravans at the same time. This left deep marks of local Egyptian dialects in some of the Swahili vocabulary even though they are very few.

Even though the origin of Arabic is the Arabian Peninsula, it later became - together with Islam and Arabic language- an important component of the African continent such that it became categorized linguistically under the Afro-Asiatic group that comprises four language families. This categorization puts Arabic, Amharic and Hebrew under the Semitic group of languages. Further, the number of Arabic speakers in Africa is much larger than those in Asia and Muslims in Africa constitute about $50 \%$ of the inhabitants in the region among those who use Arabic on a daily basis in their prayers and other religious activities. All this points to the place of Arabic in Africa and also its influence on African languages because it is used daily among Muslims in most parts of the African continent. As such the influence of Arabic on Swahili language is deeply entrenched since Swahili is a combination of a Bantu language and Arabic vocabulary and a few words from Asian and English languages. In other words, it is one of the Bantu languages that was largely influenced by Arabic. Based on this observation, we find that Swahili is full of words of Arabic origin in many spheres of life. Arabic conjunctions and numbers have become part and parcel of Swahili language including: /7a, lakini, ama, au, hata, kama, baada, bila, baada. Examples of some Swahili words of Arabic origin include, but not limited to: kitabu, karatasi, kalamu, waziri, wizara, afya, siha, siraji, haji, ahadi, dini, amri, wakati, kamusi, methali, maana, aibu, kaburi, adhabu, sura, juhudi, faida, akili, thawabu, dhiki, tashbihi, majazi, kinaya, istiara, riwaya, kisa and many others. In addition,, numbers used in 
Swahili and are of Arabic origin include: sita, saba, tisa and tens - from twenty to ninety, a hundred and a thousand.

\section{- Objective of the Research}

This research is a study on the influence of Arab and Egyptian in Swahili language and literature in the East and Central Africa region. The history mentioned the roll of Egypt in the region from the time of the Pharaohs to date as well as the interest of Arabs from the Arabian Peninsula through their trade relations which have deep historical roots from the time of the advent of Islam. The study also discusses the influence of Arabic culture in Swahili and African culture. Arabic influence on Swahili language and literature is considered to be in the form of borrowing of about 30\% of Arabic words into Swahili. The paper also outlines the trend taken by Arabic and areas where it spread so that the reader may have a clear picture of the source of Arabic language before it spread to the East and Central Africa region.

\section{- Areas where Arabic Spread}

Arabic remained confined to the Arabian Peninsula for a long time up to the advent of Islam with the mission of Prophet Muhammad (P.B.U.H) in the first half of the $7^{\text {th }}$ century. From then on, and with the spread of Islam in the Arabian Peninsula, migration movements and Islamic conquests began, thereby providing Arabic with a wide sphere to spread to especially in the lands where Muslims conquered. This shows that the spread of Arabic went hand in hand with the spread of Islam. This is considered one of the major reasons for the rapid spread of Arabic which was able to challenge other languages and exert itself within their own territories. Arabic became the language of rulers in the countries which were conquered and subsequently became the language of administration. It was also the language 
of Arab traders who played a big role in the spread of Islam and Arabic language together wherever they went to. Arabic language spread in all parts of the Arab world which comprises 21 countries in both Asia and Africa that stretch from the Arabian Gulf in the East to the Atlantic Ocean in the West. Because of their distinct location, whereby Arab countries lie along the Red Sea, the Mediterranean Sea, the Arabian Gulf and the Indian Ocean, the areas where Arabic spread to surround the East and Central Africa region from all sides. To the west is the Arabian Peninsula which is separated from the East Coast of Africa by the Red Sea and the Gulf of Aden, to the north is Egypt and Sudan which are linked to the countries of the Nile basin. As such, Arab migrants went eastwards from the Arabian Peninsula and northwards from Egypt and Sudan.

It may be said that the influence of Arabic in Swahili language and culture may include some countries of the Nile basin from central and eastern Africa at the cultural, economic, social and linguistic levels. This influence took two forms: one, from the North through Egypt which has deeply entrenched relations with countries of the Nile basin due to Egypt's interest in these countries from time immemorial. Secondly, from the East through the Red sea and the Arabian Gulf towards the Arabian Peninsula. These relations date back to the period before the advent of Islam through seasonal trade expeditions made by Arab traders in ancient times who later settled in large numbers along the East Coast of Africa. Based on this, interest in the countries in East and central Africa is not limited to Egypt only, but extends also to other Arabs in the Arabian Peninsula and this was long before the advent of Islam. As for the interest of Egypt in the countries of the Nile basin, this sprung from its search for the source of the Nile river, and the need to preserve its waters, since this great river means a lot to Egypt and Egyptians from the dawn of time and as a result of Egypt's strategic location on 
the African continent. As for the interest of Arabs from the Arabian Peninsula in the region, this sprung from the age old trade relations between the Arabian Peninsula and ancient Abyssinia and the East Coast of Africa. This relation took commercial and religious forms even though the eastern direction is what was influenced more politically, culturally and linguistically.

\section{- Afro-Arab Interactions on the East Coast of Africa}

Interaction between peoples is done through language and this is what pushes a people to learn another people's language, or language influencing another language. The natural phenomenon is that the language with a strong civilization background will influence the language with less. Given that Arabic then had its own culture, history and civilization, it loaned many words to Swahili which is a Bantu language.

Given that Swahili has been influenced a great deal by Arabic, some people even believe that Swahili sprung from Arabic language while others thought that it is a combination of two languages. Arabic and Bantu, but the more accurate position is that Swahili is a Bantu language that has been influenced a great deal by Arabic. This influence is much greater along the coast but reduces gradually as we move in the interior of East Africa. However, we find ourselves posing a logical question, how did these Arabic words enter into the Bantu language and became part and parcel of its lexicon?

To answer this question, it may be said that Arabs, with their civilization, written language and need to communicate with the inhabitants of East Africa to promote their trade, made the initiative to learn simple Bantu words so that they are able to communicate with the locals and later added to it some Arabic vocabulary. As such, it can be said that much of the Arabic influence in Swahili is in the form of sounds, words, phrases, 
proverbs and wise sayings, which were introduced by Arabs themselves into Bantu language in an effort to communicate with the locals. These were then adopted by the locals in their new forms. We cannot deny that the process of borrowing of Arabic words into Swahili must have happened at a later stage after the Arabic words had taken up the grammatical forms of Bantu language. We now turn to the influence of Arabic from Egypt and Sudan towards the Eats and Central Africa region.

- The Interest of Arabs from the Arabian Peninsula in the countries of the Nile Basin

Having discussed the interest of Egypt in the countries of the Nile basin, we now turn our discussion to the relationship that existed between Arabs from the Arabian Peninsula and the East Coast of Africa region given that the two regions are separated only by the Red Sea and the Indian Ocean. This will give the reader a complete picture of the influence of Arabic on Swahili language and literature in the countries of the Nile basin in the linguistic, cultural, economic and political spheres. A reader of history and archeological studies will find that the relationship between the East African Coast and Arabs, particularly from the Arabian Peninsula dates back to many centuries. This was helped by the distance between the two regions which lie along the Indian Ocean as well as by geographical factors in the form of seasonal winds that blew between the coasts of East Africa and the Arabian Peninsula whereby the North-Eastern winds blowing during the winter beginning from December and continued to the end of February. These helped the caravans that came from the Arabian Peninsula towards the East Coast of Africa. During summer, the opposite happened where winds blew south-west from July and which helped caravans from East Africa towards 
the Arabian Peninsula. ${ }^{(1)}$

This is how the Arab traders organized their caravans to the coast of East Africa based on the movement of trade winds. These sea caravans between the two regions were essentially trade caravans as is confirmed by the writings of many European scholars of history who arrived on the East Coast of Africa in the $7^{\text {th }}$ C A.D. ${ }^{(2)}$

With the advent of Islam, these caravans took on a religious form besides trade. Upon settling along the coast, Arabs began to mingle with the local population through marriage. There emerged a new Arab-African generation with features of both groups, and who were mainly Muslims. With the big number of Arabs settling the coast of East Africa, they established residences and business enterprises which later became the link between them and their brothers in the Arabian Peninsula. This relationship led to the establishment of Arab Emirates along the East African Coast characterized by Arab features in terms of customs and traditions alongside the African systems, cultures and traditions that were abound in the region. This played a big role in the borrowing of Arabic words into the local African

1 - أبو عجل، محمد إبراهيه، الأدب السواحيلي الإسلامي، سلسلة آداب الشعوب الإسلامية، الإدارة العامة للثقافة

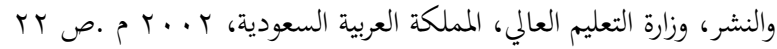

2 Posnansky, Merrick, Prelude to East African History, Oxford University Press, London, Nairobi, 1966, pp. 105-106.

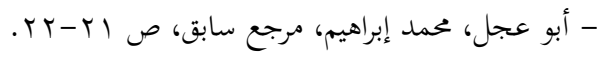

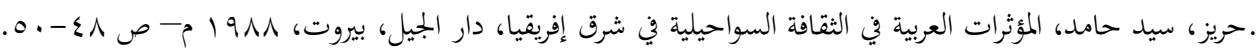

- Hollingsworth, L.W., Historia fupi ya Pwani ya Afrika Mashariki, Translation in the East African Literature Bureau, Macmillan \& Co LTD, 1966, pp. 2, 3, 15, 16. 
dialects which later became known as Swahili by Ibn Batuta. ${ }^{(3)}$

We shall now discuss this influence in detail towards the end of this paper and provide a list of Swahili words of Arabic origin. Contacts between the Arabs and Africans in East and Central Africa led to the influence of Arabic culture on Swahili culture in the form of customs and traditions in regions along the coast as well as the adjacent islands of Zanzibar, Pemba and Mavia. This influence is seen in the form of foods, clothing, housing and some customs and traditions related to birth, circumcision, marriage and death, together with religious festivals such as Ashura. These Arabic traditions became part and parcel of the Swahili culture. For example, men wear long robes (kanzu) and caps (kofia) while women put on the Arabic veil. However, the inhabitants of the region still preserve their forms of African dress besides the Islamic dressing.

As for the customs of marriage and birth, the influence of Arabic culture is seen in some of the dances of African origin which had Arabic vocabulary in them. This means that the Islamic faith was an important support link for the Swahili society in spite of the fact that some of the daily practices of the local population were influenced largely by African beliefs such as the belief in spirits and 'jinn' in addition to Islamic rituals like Idd-ul-Fitr and Idd ul-Adha which are celebrated by the rest of the Muslim population in the region. Furthermore, there are some practices

r أبو عجل، محمد إبراهيم، الأدب السواحيلي الإسلامي، سلسلة آداب الشعوب الإسلامية، الإدارة العامة للثقافة والنشر،

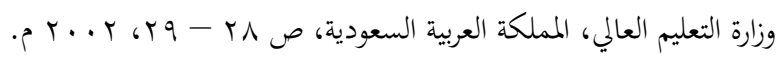

- Hollingsworth، L.W., Ibid, pp. 27-28-36-37.

- Posnansky, Merrick, Prelude to East African History, Oxford University Press, London, Nairobi, 1966, pp. 105-106.

- Hollingsworth, L.W., Historia fupi ya Pwani ya Afrika Mashariki, Translation in the East African Literature Bureau, Macmillan \& Co LTD, 1966, pp. 2, 3,15, 16. 
done during the Ashura festival which are not Islamic in nature despite the fact they should be purely Islamic. ${ }^{(4)}$ Even then, the same Arab-Islamic customs and traditions still bear the same Arabic names in the Swahili lexicon.

As a result of the Arabic influence in the customs and traditions of the African population, Swahili language, with its Bantu vocabulary, started taking a new form being a combination of Arabic and Bantu features especially in the borrowing of Arabic vocabulary into Swahili.

Tanzania is regarded as having the highest number of Swahili users at the national level in all the various spheres of life given that Swahili is the national as well the official language. Swahili is also considered the official and national language in Kenya, but in the rest of the countries in East and Central Africa, Swahili is considered a lingua franca with the most widespread usage in the region. It is used by the highest number of people irrespective of their differences in their languages and dialects.

The East African coast is regarded the origin of Swahili together with the adjacent Islands of Zanzibar, Pemba, Mavia and Mombasa where the population in these regions speak Swahili as the first language (L1). With the spread of Swahili inland, it

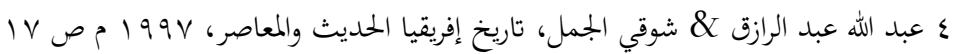

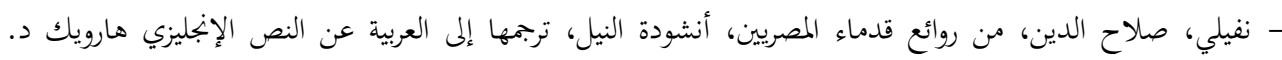

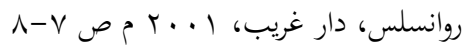

- Alfred. M. M'Imanyara, The Restatement of Bantu origin and Meru History, Longman Kenya, 1992, pp. 4-13.

- Posnansky, Merrick, Prelude to East African History, Oxford University Press, London, Nairobi, 1966, pp. 105-106.

- Hollingsworth, L.W., Historia fupi ya Pwani ya Afrika Mashariki, Translation in the East African Literature Bureau, Macmillan \& Co LTD, 1966, pp. 2, 3, 15, 16. 
became the second language of many people as well as the language of communication among the people.

In view of the historical and political circumstances prevailing in the region then, there developed a strong relationship between the local languages and Arabic even though -as was the case with English, French and Turkish and Germany- Arabic influence on Swahili is more pronounced due to the continuous contact between Arabs and their Bantu language. This relationship was manifested in the large number of Arabic words borrowed into Swahili, especially along the coast of East Africa and the neighboring Islands given that many of the inhabitants and these Islands trace their roots to the Arabian Peninsula and the Arabian Gulf.

\section{- The Role of Islam in the Spread of Arabic Language}

With the spread of Islam in East Africa, the influence of Arabic culture increasing tremendously among the inhabitants of East Africa. This influence dominated all forms of life ranging from behavior, ideology, tradition and religion. Islam as a religion and a culture penetrated the society in a very fundamental way and contributed in a big way to its social and cultural fabric. Under the banner of Islam, countries in the horn of Africa adopted an Arab-Islamic culture with each being influenced by the Arabs who settled along the coast and from whom they adopted Islam. As such, the Arab- Islamic culture flourished I most large towns along the coast of East Africa. Muslims also gradually revived religious ceremonies by presenting religious as well as praise songs and beating drums. That was evident in marriage ceremonies, Mawlid ceremonies to celebrate the birth of Prophet Muhammad (P.B.U.H) as well as during the blessed festivals of Idd-ul-fitr and Idd-ul-Adha. Islamic and Arabic stories of the holy Prophets told had a fundamental influence on members of the society in East Africa. 
In this regard, we could say that the influence of Arabs penetrated in Swahili language and culture a long time ago, but thereafter, this influence began to diminish little by little as a result of the entry of western colonialism in the region.

As a result of the widespread presence of Arabs in the coast of East Africa, there developed a strong relationship - as was stated above - between the original inhabitants of the region and Arabs who came to the region. This resulted in the influence of Arabic language that is so evident in Swahili language in various fields, particularly in language, literature, customs and traditions. In language, we find that Arabic, then, was already a written language with an entrenched culture and civilization, whereas African language was unwritten, spoken by a group of Bantu tribes in specific areas. As such, the Bantu language was unable to resist the cultural wave that blew towards the East Coiast of Africa from the Arabian Peninsula. Consequently, the Bantu language began to borrow words slowly from the language of Arabs who settled in the region. With time, Arab language scholars started writing the spoken language in Arabic script and which later on became known as Swahili language. With that, Swahili language, written in Arabic script spread to many areas of East and Central Africa. Based on this, we could say that the development of Swahili language was largely correlated with the spread of Arabic language and the Arabic script. This is evident in Swahili manuscripts that are of Islamic nature and written in Arabic script and which are dated more than 5 centuries ago. ${ }^{(5)}$

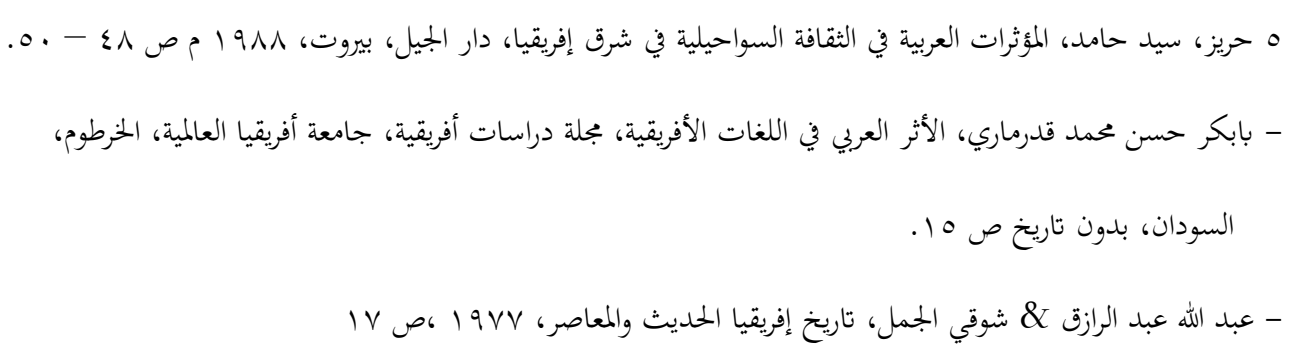


This means that Swahili language is fundamentally linked to Islam and Islamic concepts in all fields including poetry, given that the rulers of the region during that period were Arabs of Yemeni origin who confessed the Islamic religion and spoke Arabic language. Their influence led to the borrowing of a large number of Arabic vocabulary into Swahili language and literature particularly in Swahili poetry, given that poetry was considered the most important form of literature embraced by scholars and other educated people at the time. This included vocabulary in rhetoric and prosody. It is during this period that poetry flourished a great deal along the coast of East Africa characterized by long poems written in Arabic script and with Islamic content. These poems are still present today in the form of manuscripts in Arabic script found in large measure at the Universities of London and Daresalaam. 
Arabic influence in Swahili language dates back to many centuries reflecting the big role that Arabs played in East Africa in the form of their activities in culture and religion, making Swahili one of the most important languages in sub-Saharan Africa. It is therefore not possible for a researcher or student of language to deny this Arabic influence in Swahili which covered all spheres of Swahili language, religion, culture, politics, economy, science and literature. The religious field is regarded as having been influenced more and thus is a natural phenomenon because the earliest contact between Arabs and the Swahili people was based on Islam. Arabs spent a great deal of time teaching the locals religious matters. Their stay led to intermarriage between the two peoples thereby producing a new generation of people with Afro- Arab features and spoke Swahili language.

\section{- The Role and Interest of Egypt in the Countries of the Nile Basin}

There is no doubt that the source of the River Nile has been of great significance to Egypt through history for it is the artery of life for Egypt and the Egyptian people. As such, ancient Egyptian poets did not overlook this fact and so they composed several poems in praise of the Nile which were recited at the annual Nile festival. The Nile song is regarded as the most marvelous poem done by Egyptian poets among them Anana, an Egyptian poet who lived during the reign of the $19^{\text {th }}$ ruling family between 1300-1266 B.C. It was written on two pages of burda tharifan by the name Sir Waanstas which are found in the British museum. This is evidence of the Egyptians' interest in the Nile in recognition of its advantages in the form of irrigating their land thereby improving their lifestyles. Ramsis Il was one of the Egyptian rulers most interested in the Nile festivals and ordered that the festivals be held twice in a year, the first towards 
the end of May when ancient Egyptians believed was the beginning of the Nile floods at the source of the Nile. The second was celebrated on the $4^{\text {th }}$ of August when the Nile waters reached the Sisila mountains near Adfo in the Egyptian desert in the west.

Given that this is the role of literature which mirrors life in society in terms of its weather and celebrations, this is also reflected in the great interest Egyptians had in the source of river Nile and went out in search of the source which they glorified.

On the other hand, epigraphic discoveries of the Pharaohs in ancient Egypt (300 B.C) showed that the source was between Egypt and Nubaland to the south since time immemorial. This explains the attempts by ancient Egyptians to go towards the south across the Nile in search of its source. Archeological discoveries also show that ancient Egyptians helped in setting up communication routes with Nubaland through the Nile and were able to overcome a number of natural barriers in the efforts of some to reach the source of the Nile. Epigraphic discoveries also showed that ancient Egyptians had trade relations with the inhabitants of regions along the coast of the Red Sea. These relations intensified after the establishment of the modern state of Egypt especially during the reign of Queen Hatshbsut who visited Puntland in Somalia as well as Eriotrea.

The interest of Egyptians in the issue of the Nlie river increased and so they went out to trace its origin. Bathelemewz, an Egyptian of Greek origin - went out on an exploration mission where he drew a map in which he described the flow of the Nile up to the town of Marwa. He also described river ATbara and the two Niles, white and blue. It is also shown that ancient Egyptians with their Pharaonic civilization left marks in a number of countries south of the Sahara. This assumption confirms some of the claims made by some scholars archeology that some of the 
marks in Zimbabwe could be traced to the Pharaohs.

On the other hand, historical studies point to the role played by Egyptians in the contemporary period especially during the reign of Muhammad Ali and Khedive Ismail in the search for the source of the Nile and the regions along the Red Sea and the Indian Ocean. Among those who contributed to the search were scholars from Egypt and Europe with guidance from the Egyptian government. These included the Geographical explorer, James Bruce, a Scot who arrived in Egypt in 1768. He began his expedition from Egypt southwards until he reached Eksium, the capital of ancient Ethiopia, before turning towards the direction of the Blue Nile up to Lake Tana and the point of convergence of the two Niles. Again, Bakbashi Saleem Qubtan, an Egyptian navy officer during the reign of Muhammad Ali to search for the source of the Nile. He conducted three consecutive expeditions and almost reached Gendukru north of the equator. Egypt's interest in the source of the Nile extended to the period of Khedive Ismail who sent a number of expeditions which ended in the discovery of what came to be known as the Equatorial Protectorate. The explorers assisted in the movement between the regions that lay along the Nile with the support of the Egyptian in Sudan which provided security and stability.

Among the explorers also was Sir Samuel Baker who taced the tributaries of the Nile upto Habasha and also moved along the areas along river Atbara and the two Niles, Blue and White. These and other scholars assisted in the search of the source of the Nile including Gordon and Amin Basha who later became the Governor of the Egyptian Equatorial Protectorate.

A careful look at the attempts by Egyptians from time immemorial through history to date manifests their concern and interest in the search of the source of the Nile. Given their developed civilization in the various fields, there is no doubt 
they left a mark on the lives of the peoples who lived along the river Nile and the neighboring regions. This was confirmed, during an interview by the researcher in Kenya, where one of the elderly people from Lamu said that it is true that the name 'Lamu' was known as 'Amu' in the ancient Egyptian dialect, and which is taken from the name of an ancient Egyptian god, 'Amun'. This fact is strengthened by the fact that the name of the dialect is Kiamu which is also one of the dialects of Swahili language. Further, during one of the many trips the researcher made to East Africa, there still exist between Kenya and Tanzania, some tribes which trace their origin to the reign of Khedive Ismail and who call themselves Asraf (the noble). These people, with regards to their facial features and body structure resemble, to a large extent, Egyptians and still put on robes and red Turkish hats (Tarbush) and this shows the role of Egyptians in the exploration expeditions conducted during the reign of Muhammad Ali and Khedive Ismail. In addition, there is a big resemblance between their materials and agricultural tools and those used in the countries of the Nile basin and those used by Egyptians, some which are still used to date. There is also evidence of this in some of the Arabic words of Egyptian dialect found in Swahili and which are also used widely in countries of the Nile basin and which include ${ }^{(6)}$ :

Afande

Biskoti

Basha

Raisi

Adia

Waziri

6 Tuki, kamusi ya Kiswahili Sanifu, Taasisi ya Uchunguzi wa Kiswahili, O. U. P. Dar-Es

Salam, Nairobi, 1981. 
Asilan

Abadani

Bafta

Bahaimu
Misri

Bahaluli

Bawabu

Bawasiri

Balasi

These words have their origin in the Turkish language but got into Swahili through Egyptians during their continued travels in search of the Nile source, particularly during the reigns of Muhammad Ali and Khedive Ismail who were remnants of the Ottoman Turkish rule in Egypt.

The Egyptian influence in Swahili literature is also shown in the oldest Swahili manuscript written in Arabic script in a translation of the Hamziya poem written by an Egyptian poet, Abi Abdulla Muhammad ibn Saeed El Busiry. This is a poem that is widely known in Swahili literature as Hamziya. The manuscript is in form of an Arabic verse and below it is a Swahili translation written in Arabic script.

\section{A section of the Arabic manuscript with its Swahili translation in Arabic script.}




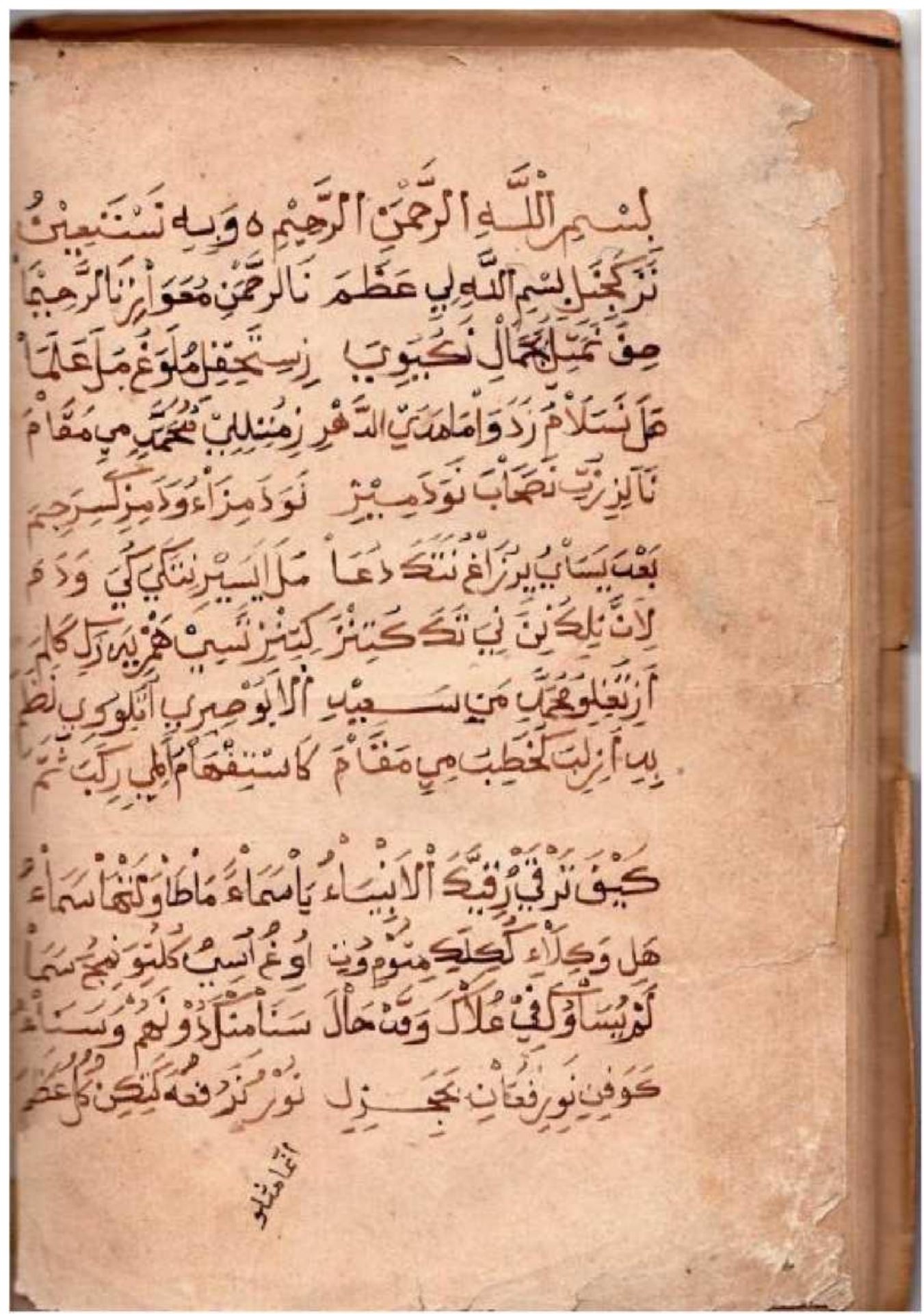




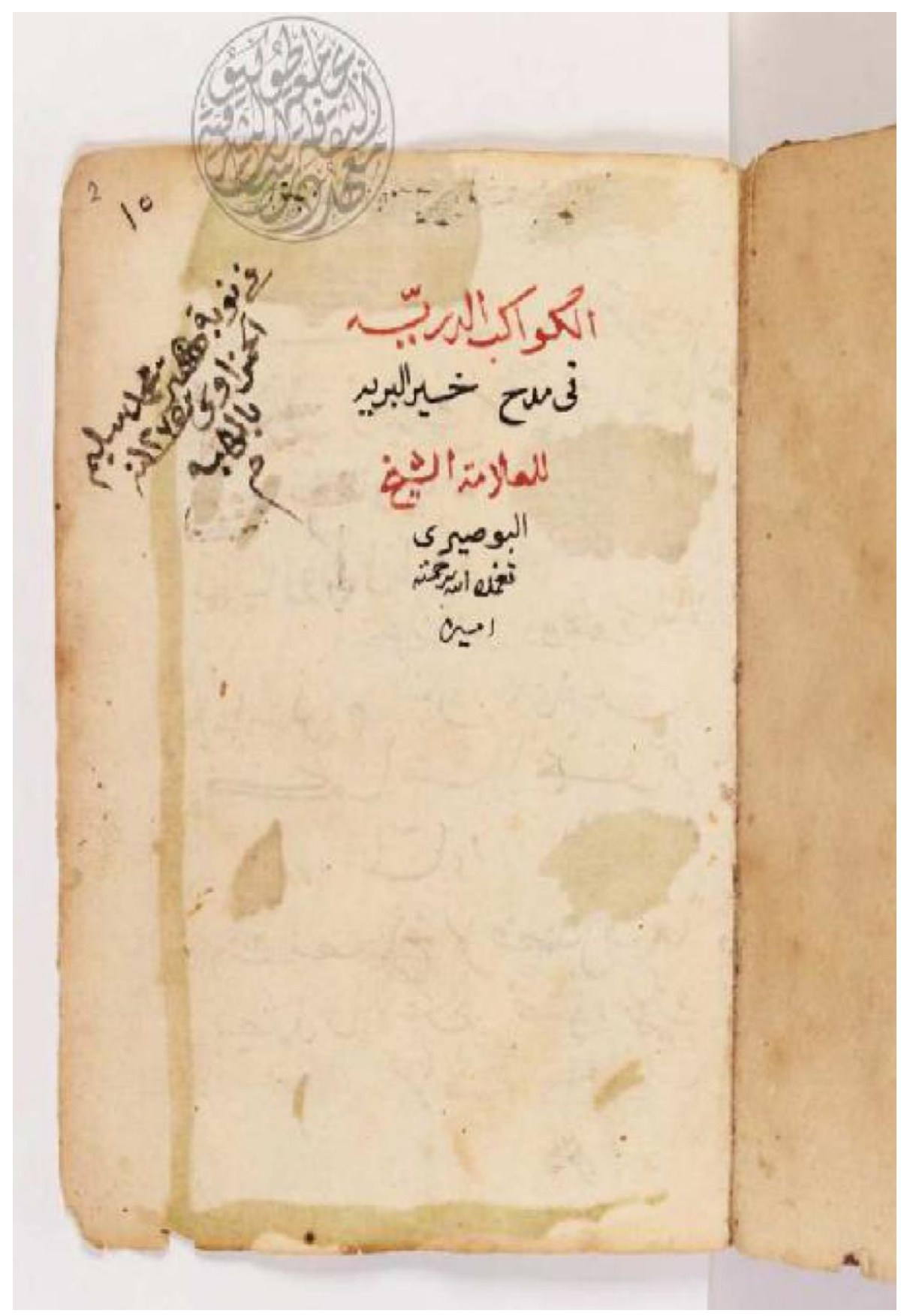


Dr. Ayman Ibrahim Al A'sar

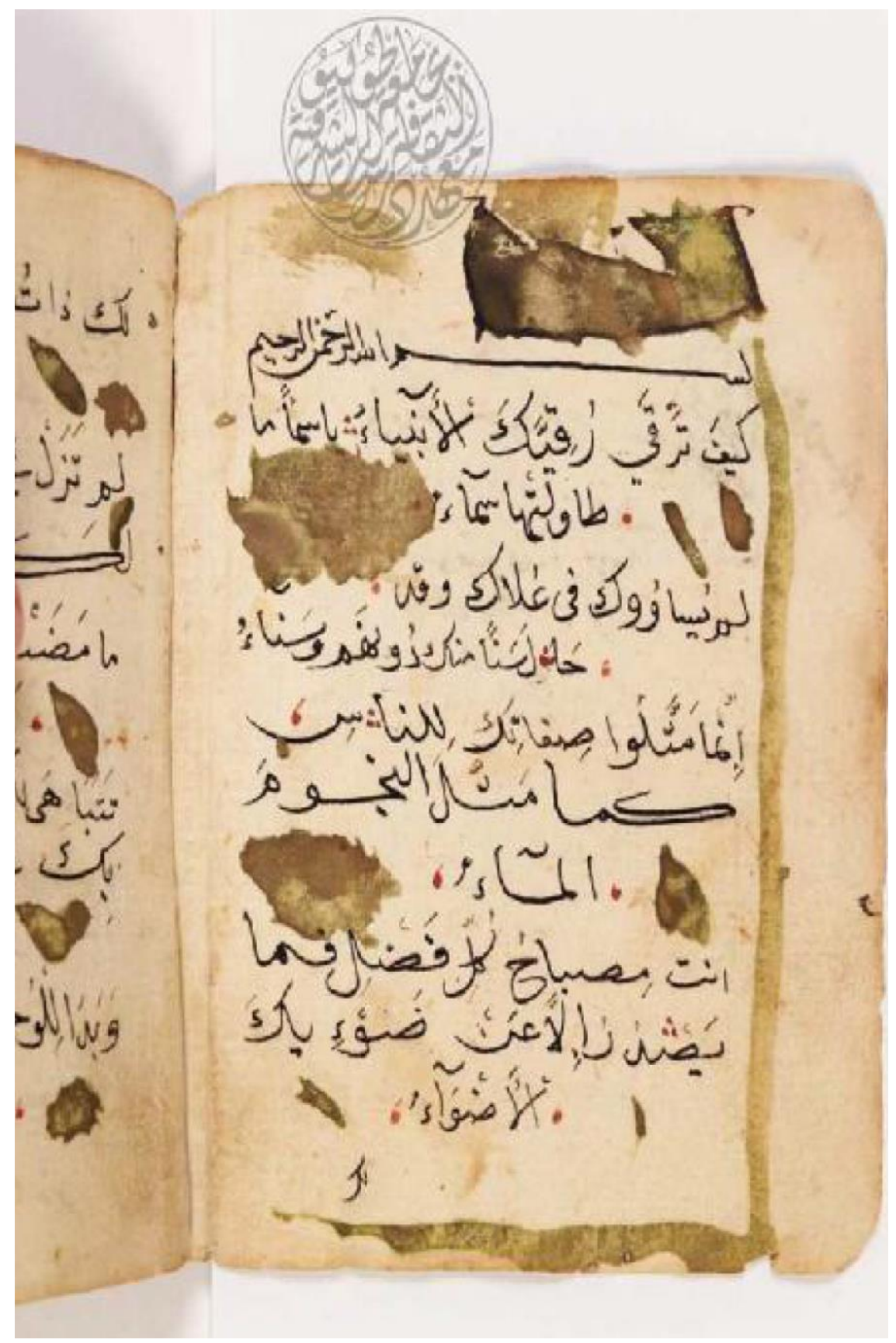




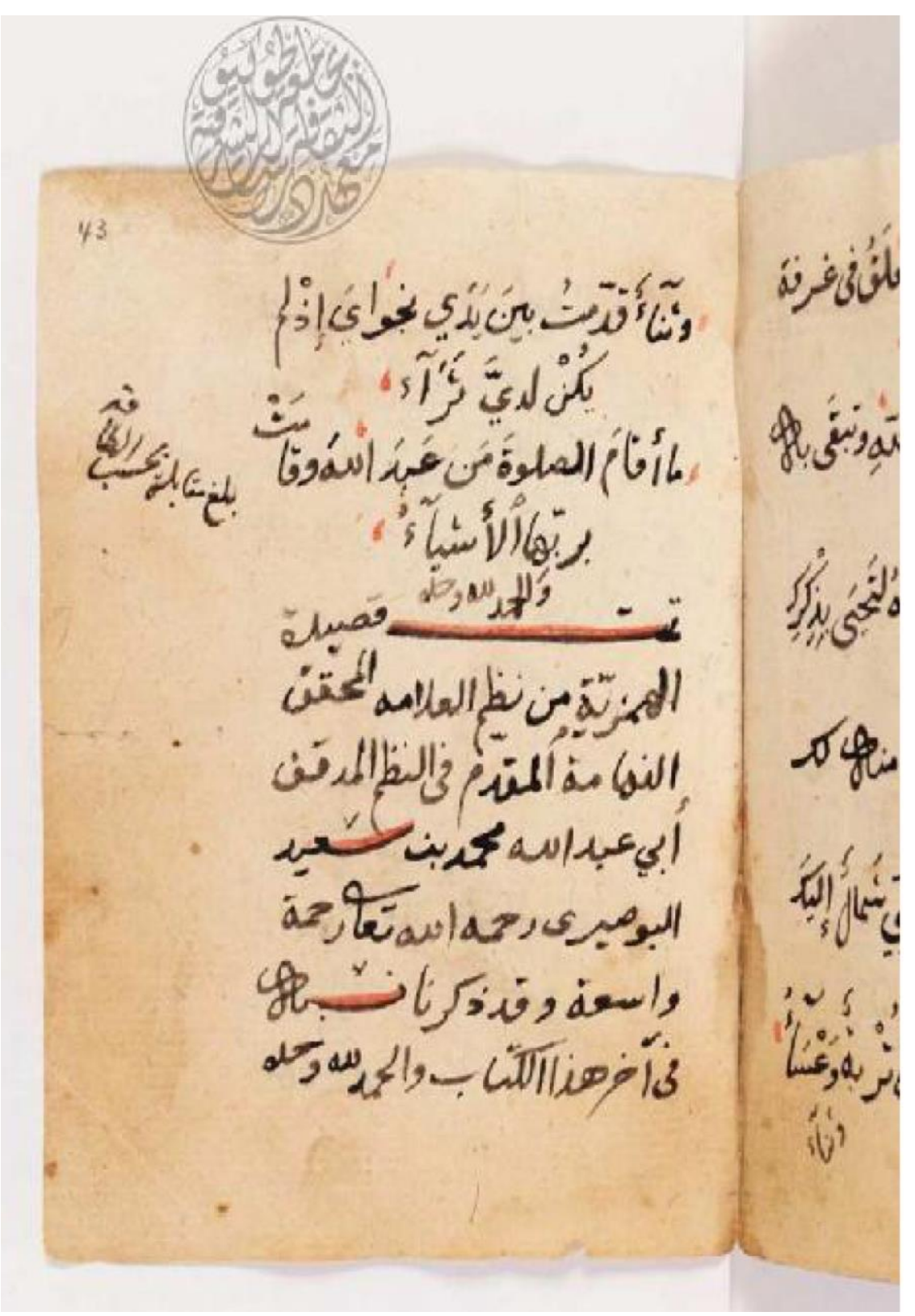

In addition, the Swahili people from Mombasa, Lamu and Malindi up to today are still fond of listening to the recitation of the Holy Quran by Egyptian reciters such as Abdel Basit and ElHasry among others. In music, elderly Swahili people are still fond of listening to Egyptian music by people like Umm kulthum and Abdel wahab. This points to the influence of Egyptiyptian relations in general and specifically with countries of the Nile basin have in the recent past taken a positive form as compared 
to the past due to the secondment of Egyptian experts in different fields to African countries to offer their expertise through the Egyptian Fund for technical Cooperation with Africa in the Ministry of Foreign Affairs. In this framework, Egypt responds to the needs of the African countries in fields such as medicine, engineering, agriculture, education etc. This has contributed to awareness among thr benefactors among them Swahili people. This has also helped in strengthening the cultural political, economic and commercial links between Egypt and African countries.

The influence of Arabic in politics and economics

As for the influence of Arabic language in the two spheres of politics and economics, this can be attributed to Arab traders who kept visiting the east coast of Africa and who carried out trading activities between the Arabian Peninsula and the East Coast of Africa, later settling in the region. This resulted in a big wave of Arabs who settled at the coast and with time became rulers in the region. Consequently, we find a number of Arabic words in the fields of politics and economics borrowed by Swahili language such as: do/a, ra/s, waziri, malik, sultan, iktisadi, tijara. These words took two forms. They either got assimilated into Swahili vocabulary within the Swahili lexicon or took on other meanings within the lexicon and which got accepted by Swahili scholars for lack of a synonymous Swahili word of Bantu origin and more so in the two areas.

\section{*The influence of Arabic in the fields of Mathematics, Calendar, Chemistry and Geography}

In addition, Swahili borrowed from Arabic vocabulary in the fields of mathematics, calendar, chemistry and geography. These are not as many compared to those borrowed in the fields of religion and literature. In mathematics, the number of words borrowed are about 350, in the field of calendar about 128 words, in chemistry about 50 words while in geography there are about 44 words of Arabic origin. This is a reflection of the activities of Arabs in the past in East Africa and their influence 
on Swahili society in all the fields of language. ${ }^{(7)}$

\section{*The influence of Arabic in literature}

\section{(i) Poetry \\ (ii) Prose \\ (i) Poetry}

In a discussion of the influence of Arabic on Swahili language in the fields of literature, we find that this is manifested largely in poetry and the various concepts of literary rhetoric. For example, we find that the influence of Arabic in poetry is not limited to Arabic vocabulary only, but extends to the various forms of Swahili poetry. This can be attributed to the fact that poetry was the main concern of intellectuals in East Africa especially those of Arabian origin. Thus, the spirit of Islamic values are dominant in most Swahili literary forms especially in the written form of literature where manuscripts date back to the $14^{\text {th }}$ century particularly in poetry as is the case of the 'Hamziyya' poem by the Egyptian poet, El-Busiry-as was stated earlier on- written in Swahili language using the Arabic script in 1330 A.D. There is also local Swahili poetry which carries the features of African writings as well as poetry written in Arabic language by those who preserved their Arabic language from the Swahili people of Arabian descent. Among them are those who lived in Lamu, Malindi and Mombasa. There are also Swahili poems translated from Arabic. The most frequently used Swahili meter is the 'Utenzi' which has been influenced by Arabic culture. It is of the 'tarbia' form because it comprises four verses. This form of poetry is well- known in Arabic culture and is also used a lot in Persian poetry. A classic example of this is the Rubaiyat al-khiyaam. Anybody tracing the origins of Swahili poetry will find that it mainly addressed Arabic Islamic issues as was the case in the poems that addresses the tales of the Prophets and earlier Muslim personalities. An example of this kind of poetry is Al-lnkishafi and other poems which focused on sermons

V الحلوجي، معطفى حسين، العلاقة بين العرب وشرق إفريقيا في الحساب، دار الكتب، ـ199 م ص ب-\&. 
and providing guidance like waji waji Utendi wa Tabaraka, Mawaidha ya Ramadhani, Adhabu ya Jahannamu etc which were written in Arabic script. This type of poetry may be referred to as religious poetry.

In addition, there is another form of Swahili poetry written in Arabic script and which may be referred to as poetry of counsel. Examples include 'Mwanakupona' and 'Siraji'. Both are a form of counsel with the former being counsel from a mother to her daughter and the latter being counsel from a father to his son in what the father and mother would wish their son and daughter to be in terms of good conduct in life. Swahili poetry also addressed issues of praise as in the case of 'Hamziyya' regarded to be the oldest Swahili manuscript written in Arabic script, Mawlidi ya Barzanji, Utenzi wa maisha ya Mtume Muhammad (S.A.W) also referred to as Ruwaza Njema as well as Miraji. These poems focus on praising the Prophet (P.B.U.H). However, this type of poems was not limited to praising Prophet Muhammad alone, but also praised other prophets like Adam, Idris, Noah, Hud, Salih, Abraham, Lot, Ismael, Isaac, Jacob, Joseph, Job, Dhulkifl, Moses, Aron, Jesus, Zakariyya etc. A reader of these Swahili poems will notice that the poets adopted the Holy Quran, the Prophetic tradition and books on the tales of the Prophets written in Arabic as major sources of the content of their poems written in Arabic script.

\section{(ii) Prose}

With regards to prose, we find the influence of Arabic evident as in the poem on Isra and Miraj (the Prophet's ascension to the heavens and back), stories of ABunuwas, Harun Rahid and 'Alfu Lela wa Lela'. Further, we find the stories of Prophets seem to match the stories of the Prophets found in the holy Quran. On the other hand, we find the influence of Arabic very clear in the Swahili proverbs and wise sayings similar in letter and spirit or in terms of meaning only or a combination of Bantu and Arabic languages, and which have meaning similar to the Arabic proverb. Below are some examples :

1. Haraka haraka haina baraka . 
2. Subira huvutu heri.

3. Akili ni mali.

4. Ahadi ni deni.

5. Kalamu ya Mungu haikosi.

6. Kila kufuli na ufunguo wake.

7. Kila shetani ana rafiki yake.

8. Rafiki akufaaye wakati wa shida ndiye rafiki.

9. Subira ni ufunguo wa faraja.

10. Subira ni ufunguo wa heri.

11. Sumu ya deni kulipa.

12. Taabu ya mtu ni ndiyo raha yake.

13. Tahadhari kabla ya hatari

14. Utii ni bora kuliko kafara.

15. Zamani hairudi.

16. Maisha matamu lakini mafupi,

17. Maiti haina lawama.

18. Mali bila daftari hupotea bila habari.

19. Malipo ni duniani, ahera yaenda hesabu.

20. Radhi ni bora kuliko mali.

Below are examples of Swahili vocabulary of Arabic origin in the fields of language and literature:

Asubuhi

Bila

Haja

Arubaini

Dawa

Hakimu

Ardhi

Dua

Halali

Ajabu

Dunia

Hakika

Azizi

Faida

Haramu 


\begin{tabular}{|c|c|c|}
\hline Adhabu & Fikira & Hekima \\
\hline Akbaru & Firdausi & Huru \\
\hline Habari & Fitina & Hukumu \\
\hline Asili & Ghaibu & Ibada \\
\hline Baada & Ghairi & Ibni \\
\hline Baiti & Ghadhabu & Binti \\
\hline Bata & Ghafla & Hisani \\
\hline Baadhi & Hakimu & Elimu \\
\hline Balaa & Habibu & Imani \\
\hline Imtihani & Insani & Jahili \\
\hline Jeneza & Janatu & Jawabu \\
\hline Kabiri & Kalamu & Karimi \\
\hline Khairi & Kitabu & Kufru \\
\hline Kila & $\mathrm{La}$ & Lazima_Labuda \\
\hline Lugha & Lulu & Mali \\
\hline Malaika & Mauti & Nafsi \\
\hline Nikahi & $\mathrm{Nia}$ & Nuru \\
\hline Nabi & Rabi & Sadiki \\
\hline Rafiki & Rehema & Safi \\
\hline Sahibu & Sahili & Salamu \\
\hline
\end{tabular}




$\begin{array}{lll}\text { Sababu } & \text { Subira } & \text { Safari } \\ \text { Shairi } & \text { Shekhi } & \text { Shetani } \\ \text { Sharef } & \text { Sharti } & \text { Shukuru } \\ \text { Siri } & \text { Tarehe } & \text { Tabasamu } \\ \text { Tajriba } & \text { Takriban } & \text { Taqwa } \\ \text { Umri } & \text { Wakili } & \text { Watani } \\ \text { Yatima } & \text { Dhikri } & \text { Ziara } \\ \text { Raisi } & \text { Waziri } & \text { Iktisadi } \\ \text { Wizara } & \text { Karatasi } & \text { Mahali } \\ \text { Bustani } & \text { Sultani } & \text { Maarufu } \\ \text { Nusuru } & & \end{array}$

Below are examples of Swahili literary words of Arabic origin:

$\begin{array}{lll}\text { Fasihi } & \text { Riwaya } & \text { Uhakiki mpya } \\ \text { Futuhi } & \text { Sanaa } & \text { Uhakiki wa filamu } \\ \text { Hadithi } & \text { Sitiari } & \text { Uhalisi nafsi } \\ \text { Hurafa } & \text { Taswira } & \text { Uhalisi wa kirasimi } \\ \text { Makala } & \text { Uhakiki } & \text { Uhalisafifi } \\ \text { Lugha } & \text { Uhalisi } & \text { Uhalisiajabu } \\ \text { Maana } & \text { Urasimi } & \text { Ushairi historia } \\ \text { Matini } & \text { Ushairi } & \text { Ushairi wa kidrama } \\ \text { Nadharia } & \text { Majazi } & \text { Ushairishaji }\end{array}$


Msanii Mshairi Mhariri

Mizani

\section{References}

1) Alfred. M. M'lmanyara, The Restatement of Bantu origin and Meru History, Longman Kenya, 1992.

2) Hollingsworth, L.W., Historia fupi ya Pwani ya Afrika Mashariki, Translation in the East African Literature Bureau, Macmillan \& Co LTD, 1966.

3) Posnansky, Merrick, Prelude to East African History, Oxford University Press, London, Nairobi, 1966.

4) Tanzania kabla na baada ya Uhuru, Institute of Adult Education, Dar-Es Salam, East African Literature Bureau, 1977.

5) Tuki, kamusi ya Kiswahili Sanifu, Taasisi ya Uchunguzi wa Kiswahili, O. U. P. Dar-Es-Salam, Nairobi, 1981.

6) Tanzania kabla na baada ya Uhuru, Institute of Adult Education, Dar-Es Salam, East African Literature Bureau, 1977.

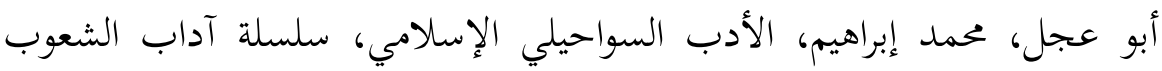

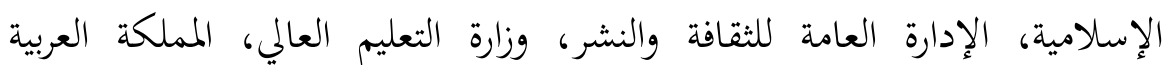

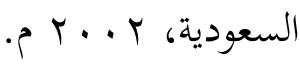

الحلوجي، مصطفى حسين، العلاقة بين العرب وشرق إفريقيا في الحساب، دار

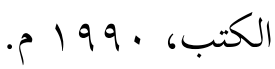

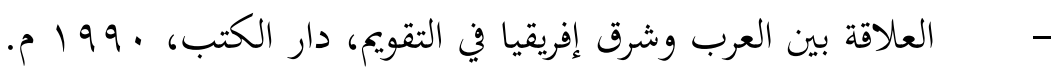

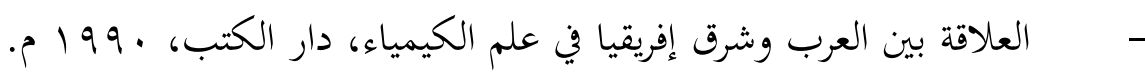

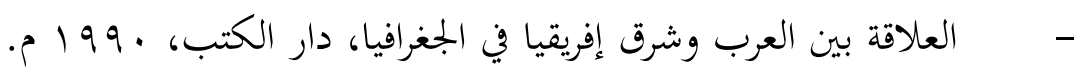

حريز، سيد حامد، المؤثرات العربية في الثقافة السواحيلية في شرق إفريقيا، دار 


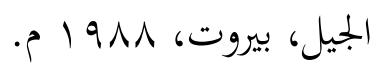

• (1) عبد الله عبد الرازق \& شوقي الجمل، تاريخ إفريقيا الحديث والمعاصر، V99 م.

(I) (1) نفيلي، صلاح الدين، من روائع قدماء المصريين، أنشودة النيل، ترجمها إلى العربية

$$
\text { عن النص الإنجليزي هارويك د. روانسلس، دار غريب، ال ـ . ب م. }
$$

Y ( ) بابكر حسن محمد قدرماري، الأثر العربي في اللغات الأفريقية، مجلة دراسات أفريقية، جامعة أفريقيا العالمية، الخرطوم، السودان، بدون تاريخ. 